\title{
The effectiveness of social work services for families whose children are in temporary custody
}

\author{
R. Bardauskiene and J. Pivoriene \\ Mykolas Romeris University, Vilnius, Lithuania
}

\begin{abstract}
Despite that there is an operating social support system for families, social workers are affected by factors that limit effectiveness of their activities in working with families whose children are taken into temporary custody. The article aims to uncover what hinders social worker to carry out effective work in providing social services for families whose children are in temporary custody. Qualitative research data shows that the research participants' awareness of social work effectiveness is limited to its individual components. Putting together these components one can get a broad definition of effectiveness of social work though the research participants themselves do not use such a concept. The research data reveals that micro level factors influencing effectiveness of social workers' activities working with families whose children are in temporary custody are as follows: absence of parental motivation to seek changes and unfavourable environment as well as negative community approach to social risk families. Macro level factors limiting social work effectiveness working with the families at social risk lie in the system of social services. Inadequate management of social work, limited social workers' access to resources necessary to restore family functions; too high workload for social workers are essential factors limiting social work effectiveness. Key words: effectiveness; social worker; social services; family at social risk; temporary child custody; permanent child custody.
\end{abstract}

\section{Introduction}

In order to achieve positive changes in social system it is necessary to analyse effectiveness of social services. Despite the fact that the issue of effectiveness has been discussed since the beginning of the development of social work profession [1], to measure it is still a big challenge for researchers [2-4]. There is no consistent system and approved methodology for the assessment of social services quality and effectiveness in Lithuania. On the other hand it is difficult to measure an intervention on the ground of success-failure dimension. There are cases, when social workers have to make a decision which is the least harmful for a client. It is especially relevant while talking about social work with risk families, when families receive professional social services but still cannot provide safe and healthy environment for a child and he or she is taken from a family. Risk families usually have many problems and require a systematic approach from professional team. 
In order to make more effective provision of social services for families at risk and to ensure children's right to grow up in family, social workers with social risk families position was established in Lithuania in 2007. It was expected to diminish the number of children who were taken out from families because of unsafe and unprotected environment. However, the Report of Ombudsmen [5] claims that the number of such cases has not diminished, social work with families is done formally only, special social services are provided insufficiently, and the causes why a child is taken from the family are not eliminated. The Report states that support system is not sufficient, it lacks services for social skills education and maintenance despite the fact that the lack of social skills is one of the main reasons why a family is enrolled in a social risk list. Psychosocial support for addicted family members has not been developed, too. Differences in infrastructure in various municipalities, insufficient number of social services providers, absence of prevention services are named as the main restrains for the effective social services provision. The legal background does not regulate assessment of social services' quality, does not define responsibilities for ineffective social services provision. In total, the restrains could be found on micro as well as on mezzo and macro levels and their elimination should be viewed in a complex way.

According to statistics [6], there were 532647 children in Lithuania, the number has decreased by 11000 (2.04\%) since 2013. However, the number of children in risk families and number of children in custody remains the same. In the Report of State Child Rights Protection and Adoption Service under the Ministry of Social Security and Labour [7] it is said that in 2014 children in risk families composed $3.7 \%$ of all children $(2012 \mathrm{~m}$. $-3.80 \%$, $2011 \mathrm{~m} .-3.83 \%$ ), the number of families whose children were in custody also slightly varied: in $2012-883$, in 2013 - 907, and in 2014 - 817. Statistical data shows little variations in numbers which means that provided social services do not reach their targets, positive changes in families are not achieved, and social services are not effective.

Measurement of the effectiveness raises many challenges for researchers. Usually such measurement is associated with business where effectiveness is defined as a rational circulation of resources which leads to positive results, e.g. profit [8], as such usage of resources which guarantees the maximal result [9], as a state when production cost is minimal but benefit is maximal [10]. However, it is impossible to apply business vocabulary to social system and to measure effectiveness of social services with the same measures as in business. L. Zalimiene (2006) says that the difference between business and social services is that in business the biggest attention is paid to profit, but in social services there is no profit. Provided social services could bring loss in economic sense but they still are necessary. The decision not to provide uneconomical social services in order to save resources could be beneficial in short term but would cost a lot in long term if the number of services users will rise. The effectiveness of social services depends on outside factors such as policy, operations of various institutions, organizations, activities of local communities, network of clients, etc., which is difficult to predict and plan. In business loyalty of clients is crucial to effectiveness and profit while in social system clients' dependence on social services means that social services are ineffective and that one of the most important social work goal is to empower client to solve problems is not achieved [11]. J. Moriarty and J. Manthorpe (2016) define effectiveness of social services as an assessment how specific intervention or policy operates in real situation. This notion includes cost-effectiveness, impact to clients, attitudes of clients and services' providers. Authors state that effectiveness also depends on abilities of a social worker to combine various roles [12].

The aim of the article is to reveal what are restrains of effectiveness of social services for families whose child is in custody. The object is restraining factors of effectiveness. 
Research questions are: how social workers define effectiveness? What are restraining factors for effective social services' provision for families?

\section{Methodology}

Qualitative case study methodology was used in the research. The case in the research is defined as an activity of a social worker with families whose child is in custody. Document analysis and in-depth interviews were used in the research.

Document analysis was made of five custody cases provided by Child protection office according to these criteria: child is in permanent custody, parental rights are restricted for an open-ended term. After document analysis cases were classified according to these criteria: situation in the family at the time of decision on temporary custody, situation in the family at the moment of application to the court for restriction of parental rights, duration of temporary custody, and the number of revisions of temporary custody.

For in-depth interviews informants were selected by criterion sample, selection criteria were social workers who were working with previously analysed cases from the decision on temporary custody till the application to the court for parental rights' restriction. Four social workers were interviewed as one worker had two cases. Interview included questions about social support system for families whose child is in temporary custody, social work effectiveness, factors which restrain to work effectively with families. Content analysis was used for qualitative data analysis. Research complied with ethic requirements, confidentiality and privacy was ensured during the research.

\subsection{Attitude of social workers to effectiveness of activities and its restraining factors}

To prove social work effectiveness is always difficult. The complex and interconnected nature of problems of families at social risk, such as alcohol, violence or poverty makes difficult to describe the effectiveness of one intervention that is highly contextual and is characterised by complex client-worker relationships from another and from the context in which it is located. For this reason, it is vital to find out what are restrains for social worker to provide effective social services to families whose children are in temporary custody.

Document analysis revealed that temporary custody and social work with family last for 8-36 months. Revision of temporary custody is done 2-3 times. In all analysed cases temporary custody was changed to permanent one, as after the revision was found that the situation in families had not changed and children could not come back to families. Interview data analysis formed three categories of the factors restraining effectiveness:

- individual (micro level);

- family and environment (mezzo level);

- social system (macro level).

Micro level factors which could influence effectiveness of social work are related with individual and professional abilities of a social worker. Qualification requirements for social workers define that a professional social worker should be able to organize effectively human, financial and other resources, while working with families at risk assessing effectiveness of provided social services. Therefore, it is important to know social workers' understanding of their work and its effectiveness. Research data shows that informants relate effectiveness with benefit and goal achievement: "What is effectiveness? I understand it as how useful it is (I)", "I think you can tell that it was effective when a child returns to family, when the situation in the family becomes better (I)", "it is seeking the goal (IV)". As was mentioned earlier the effectiveness of social work is not always possible to measure by success-failure criteria. Effectiveness of intervention relates to what was 
done and how resources were used: “... almost all resources were used (IV)”, "the goal was not achieved, but all possibilities and resources were used (IV)", "assessing effectiveness, first of all, I would pay attention not to the result but how resources were used (IV)". Effective social work depends on social workers' competence, e.g. ability to combine various roles, to apply knowledge: "consultations, communication, provision of information, leading to other institutions or organizations, all these activities lead to effectiveness (II)", "social worker is a tool for achievement of results (...), it is knowledge, education, personal traits (III)", "I understand effectiveness as social worker's ability to apply knowledge, abilities, competences in practice (IV)". Effective support should be timely: "effective work was when we reacted immediately, the same day, we made a family plan, assigned responsibilities (II)". It relates with clients' motivation and understanding of the problem: "the effectiveness depends on how much a person understands his/her problems (I)" as well as with social workers' not judgemental attitudes: "the biggest effectiveness is when you don't have negative attitude to a person, don't have preconception (II)".

Research data shows that informants present notion of effectiveness which is very close to the one defined by J. Moriarty, J. Manthorpe (2016) [13]. Social work effectiveness could be described as achievement of the goals, which change clients' situations and relates to usage of the resources as well as micro and macro factors, such as competence of social worker, attitudes to clients, timely support. However, research data reveals that informants do not have a clear and holistic vision what is effectiveness in social work.

Mezzo level factors are related to a risk family and its environment. The main factor which hinders effectiveness of social work is lack of clients' motivation: "what was lacking the most, it was a person's motivation, he didn't want to change (II)", “...absence of wish to change (III)", "she wasn't motivated, even if promised, she didn't keep these promises (III)", "a client was not ready to accept the support (IV)". It is not easy to motivate a client as motivation is influenced by inside and outside factors. It could be related with values, e.g. how important are children and how big is a wish to change for returning of children. Research data shows that for some families children are not important: "women chose to live with a cohabitant instead if living with children but without him (I)". On the contrary, parents for whom a child is important are motivated to change and cooperate with social workers: "a family was motivated to get back a child; therefore they kept commitments (III)". Other strong factors for motivation are financial resources and long-term family problems: "his problem was long-term (II)", "the most important was alcohol problem (IV)", "a person lived without any financial resources (II)". Another factor which hinders motivation is a denial of the problem; changes are possible only when a client understands the problem. Research data shows that people tend to deny their problems especially addiction one: "it is denial of the problem, especially denial of addiction to alcohol (IV)". Social workers seek to empower risk families for positive changes by educating parents parental and social skills, however, if a family is not motivated and active, activity of social worker becomes much more complicated, requires bigger time resources, higher competence, involves cooperation of various professionals.

Research data reveals a big impact of the environment, informants have told that for effective social work family environment is crucial: "environment, neighbours, friends impeded for changes, if she would go living elsewhere, where is another environment... (III)", "there were these drinking friends, who were very important (IV)". Lack of support from close environment and community leads to unsuccessful work as well: "it is necessary to get understanding of the surrounding, of the society (IV)", "there is no community which would support (III)". Negative attitude of the community prevents from effective work: "it was impossible to overcome attitude of the community that she could change (IV)". A community could hinder social worker's efforts: "a community constantly interfered to 
social worker's job, controlled her (I)". The relationship between an individual and environment is explained by system theory [14-16]. It says that individuals are in constant relation with their environment and have to adjust to never ending environmental changes. Individuals change as well as the environment. If an individual is able to develop in changing environment and receives support from the environment, it means that mutual adaptation is occurring. Risk families have difficulty with adjusting to changing living conditions and challenges raised by environment. They do not receive support from the environment and this decreases their motivation and possibility for changing the way of life.

Next to micro and mezzo level factors, macro factors are present as well, they mainly include various aspects of social system, and one of them is organizing of social work. Research data reveals that such organizational limitations as high workload, paper work decrease the possibility to give enough time to work with family: "I had twenty five families (II)", "it was not enough time for working with a family (I)", "time for family is very limited (III)", "fifty percent of my work time I spent on filling various documents and writing papers, developing plans, little time I could spent with families (III)".

Inter-institutional cooperation, as well as team work are important for social work effectiveness: "it was lack of cooperation, team work (I)", "the cooperation is impeded by other institutions' negative, stigmatized attitude to a client (III)", "it is difficult to cooperate with centres for psychical health, psychiatrist, psychologist, because they don't provide any information (III)", "there is no cooperation between various institutions (IV)". Social workers are left alone in providing social support for families: "it would be possible to achieve much more if social worker wouldn't stand alone (I)", "social worker in the villages is alone (II)", "when a child is in temporary custody, it is not enough with activities of a social worker, team work is needed (IV)", "if a family is in crisis, in fact social worker stays alone with a family in this crisis (IV)".

Research data shows the problem of social services for families accessibility: "family lives far away, they need to travel far (I)", "activities are in the evenings, there is no transport to get, there is no transport from the village to town in the evenings (IV)", "addicted to alcohol can't get services in place (III)". Informants also define shortcoming of specific social services: "there are not social housings (I)", "a client couldn't get an allowance because she is in debt for public utilities (III)". Data shows that for social workers it is difficult to ensure the principal of universality which is defined in The Law of Social Services [17]. It states that social services should be provided in combination with financial support, child protection, health, educational, housing and special assistance services.

Social workers while analysing their work experience with specific cases define obstacles which have hindered effective social work and children have been not returned to families. Competence of a social worker is one of the main micro factors which relates to effectiveness of social work with families. Next to micro factors, research participants name mezzo and macro factors which decrease effectiveness of social work. Such organizational factors as high workload, low accessibility of social services, limited possibilities to influence families' environment are described as negative factors. Research data shows that team work is regulated by law, however, it is minimal or absent at all, is formal, limited only to information exchange between various institutions while a child is in temporary custody. Social workers find difficulty in providing effective social services and in using resources rationally due to lack on inter-institutional cooperation. Shortcomings of social service infrastructure, inaccessibility of social services, complicating process for receiving financial support for a client, restraining factors to use various resources for social workers hinder effectiveness of social work. These challenges 
make impossible to achieve possible results in families' lives, to remove obstacles for successful returning child to family.

The research participants point out that their activity would be more effective if they could work in a system closely collaborating not only with the clients' environment but also with a local community, institutions, working in a team and using different and numerous resources in support process. This means that it is not enough for social workers just to intervene into micro level, but it is very important to target an intervention to mezzo and macro levels initiating changes in a community and social services system. The responsibility for social work effectiveness has to take not only social workers, but also representatives from municipalities and different ministries as well as politicians.

\section{Conclusions}

Social service system which has to ensure ability of risk family to function independently in society operates not effectively as number of children in custody is not diminishing, temporary custody often leads to permanent one.

Research data shows that the lack of parents' motivation for changes, not supportive family's environment and negative community's attitude to risk families causes not effective social work.

Effectiveness of social work with risk families is hindered by limitations of social service system.

Improper organization of social workers' activities, limited possibilities for social workers to use rationally available resources, too high work load causes non effective social services' provision.

Research participants have vague understanding about the notion of effectiveness of social work; they name many components of effectiveness but do not put them in one complex picture.

\section{References}

1. Cheetham, J., Fuller, R., Mclvor, G., Petech, A. Evaluating Social Work Effectiveness. Buckingham: Open University Press (1992)

2. Romeo, L. Annual Report by the Chief Social Worker for Adults: one year on. London: Department of Health. Prieiga per internetą: https://WWW gov, uk/government/uploads/system/uploads/ attachment_data/file/368485/Annual_report_2014_web_final. pdf (2014)

3. Davies, M. (Ed.) The Blackwell Companion to Social Work. Fourth edition. Chichester: Wiley-Blackwell (2013)

4. Adams, R., Dominelli, L., Payne, M. Social Work: Themes, Issues and Critical Debate. Basingstoke: Palgrave Macmillan (2009)

5. Lietuvos Respublikos Vaikoteisiu apsaugos kontrolieriaus 2012 metu veiklos ataskaita 2013-03-29, 4-1 Vilnius (2013)

6. Statistikos departamentas. Gyventojai ir socialine statistika. Oficialios statistikos portalas. Prieiga per internetą: http://osp . stat.gov. $1 \mathrm{t} /(2016)$

7. Valstybès vaikoteisiu apsaugos ir ìvaikinimo tarnyba prie Socialinès apsaugos ir darbo ministerijos 2014 metu veiklos ataskaita 2015-03-18, 5-2. Prieiga per internetą:

http://www.vaikoteises. lt/media/file/ataskaitos/2014\%20M _\%20VEIKLOS\%20ATASKAITA\%202015-03-18.pdf (2014) 
8. Lukaševičius K., Martinkus B., Piktys R. Verslo ekonomika. Kaunas: Technologija (2005)

9. Mackevičius J. Imoniu veiklos analizè. Informacijos rinkimas, sisteminimas ir vertinimas. Vilnius: TEV (2007)

10. Newbold D. A Brief Description of the Methods of Economic Appraisal and teh Valuation of Health States. Joournal of Advances Nursing (2005)

11. Žalimienè L. Socialiniu paslaugu vadyba: balansavimas tarp socialinio teisingumo ir ekonominio racionalumo. Ekonomika ir vadyba: aktualijos ir perspektyvos, 2006, (6), 183-189. ISSN 1648-9098

12. Moriatry, J., Manthorpe, J. The Effectiveness of Social Work With Adults. A systematic Scoping Review. King's College London. Prieiga per internetą: https://WWW kcl ac uk/sspp/policy-institute/ scwru/pubs/2016/reports/Moriarty-\&-Manthorpe-2016Effectiveness-of-social-work-with-adults.pdf (2016)

13. Moriatry, J., Manthorpe, J. (The Effectiveness Of Social Work With Adults. A systematic Scoping Review. King's College London. Prieiga per internetą: https://WWW kcl ac uk/sspp/policy-institute/scwru/ pubs $/ 2016 /$ reports/Moriarty-\&-Manthorpe-2016Effectiveness-of-social-work-with-adults.pdf (2016)

14. Pincus, A., Minahan, A. Social Work Practice: Model and Method. F.E. Peacock Itasca, Ill (1973)

15. Germain, C.B. Social Work Practice: People and Environments - an Ecological Perspective. New York: Columbia University Press (1979)

16. Andreae, D. "General Systems Theory: Contributions to Social Work Theory and Practice". In Social work treatment: interlocking theoretical approaches, ed. by Francis J. Turner. Oxford; New York (N.Y.): Oxford University Press. P: 242-254 (2011)

17. Lietuvos Respublikos socialinių paslaugų įstatymas. Valstybès žinios. 2006, 1042367 
